\title{
China invests two times as much as USA on honey bee
}

\section{research [version 1; peer review: peer review discontinued]}

\author{
Xianbing Xie ${ }^{1-3}$, Shudong Luo4, Zachary Huang ${ }^{2}$ \\ ${ }^{1}$ Department of Laboratory Animal Science, Nanchang University, Nanchang, Jiangxi, China \\ ${ }^{2}$ Department of Entomology, Michigan State University, East Lansing, Michigan, USA \\ ${ }^{3}$ College of Chemistry and Life Science, Quanzhou Normal University, Quanzhou, Fujian, China \\ ${ }^{4}$ Institute of Apicultural Research, China Academy of Agricultural Sciences, Beijing, China
}

V1 First published: 20 Jul 2015, 4:291

https://doi.org/10.12688/f1000research.6621.1

Latest published: $20 \mathrm{Jul}$ 2015, 4:291

https://doi.org/10.12688/f1000research.6621.1

\section{Abstract}

Honey bees are in no doubt the most beneficial insects to humans due to their widespread use for pollination of our crops. In this paper we compare the recent investment into honey bee research in China and USA. We show that China has invested more heavily into honey bee research than USA since 2007. The recent funding increase promised by the White House Pollinator Task Force, hopefully, will reduce the funding gap between the two countries.

\section{Keywords}

China, USA, honey bee research , funding

\section{Peer review discontinued \\ Peer review at F1000Research is author- driven. Currently no reviewers are being invited. What does this mean?}

Any reports and responses or comments on the article can be found at the end of the article.

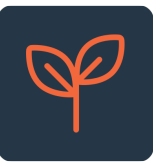

This article is included in the Agriculture, Food

and Nutrition gateway.

Corresponding author: Zachary Huang (bees@msu.edu)

Competing interests: We declare no competing interests.

Grant information: XX was supported by National Natural Science Foundation of China (\#31302040) and Natural Science Foundation of Fujian Province (\#2010j05081).

The funders had no role in study design, data collection and analysis, decision to publish, or preparation of the manuscript.

Copyright: ( $\odot 2015$ Xie X et al. This is an open access article distributed under the terms of the Creative Commons Attribution License, which permits unrestricted use, distribution, and reproduction in any medium, provided the original work is properly cited. Data associated with the article are available under the terms of the Creative Commons Zero "No rights reserved" data waiver (CCO 1.0 Public domain dedication).

How to cite this article: Xie $X$, Luo $S$ and Huang Z. China invests two times as much as USA on honey bee research [version 1; peer review: peer review discontinued] F1000Research 2015, 4:291 https://doi.org/10.12688/f1000research.6621.1

First published: 20 Jul 2015, 4:291 https://doi.org/10.12688/f1000research.6621.1 


\section{Introduction}

It is well known that honey bees (Apis mellifera in North America and Europe, but also A. cerana in Asia) are the most beneficial insects to humans due to the pollination services they provide to our fruits and vegetables (Gallai et al., 2009). The most recent estimated value of honey bees in the US was $\$ 15$ billion per year (Morse \& Calderone, 2000). This is likely underestimated: in Michigan alone, the value of fruits and vegetables that resulted from honey bee pollination was close to 1 billion per year (http://bees. msu.edu/2010/bees-worth-a-billion-in-michigan/), after adjusting for the honey bee dependency factor of each crop. For example, soybean only increases $10 \%$ of its yield after honey bee pollination, so only $10 \%$ of the total production value was used for this calculation.

\section{Funding in China}

In the following discussion, we show that the US lagged behind China in governmental investment in honey bee research. China does not seem to have suffered from the same Colony Collapse Disorder (CCD) that the US has endured since the fall of 2006 (Cox-Foster et al., 2007). The most recent survey conducted by Vander (Vander Zee et al., 2012) found annual colony loss in China was below $10 \%$. Yet, since 2008, China has invested much more than the US in honey bee research. In their Earmarked Fund for Chinese Modern Agro-industry Technology Research System, (shortened as CARS [sic]), a chief scientist, Jie Wu was chosen, who then assembled a team of 19 additional scientists nationwide (Wu, 2009). These scientists were organized into 6 laboratories, though most members in each laboratory were not located at the same institution (Table 1). A total of \$19 million USD has been granted to these scientists since 2008. In addition, 21 honeybee-specific experimental stations were funded at a slightly lower level with a total of $\$ 10.2$ million USD across the two funding periods (Table 2). An independent project for pear pollination in northern China was funded for 15 million RMB ( $\$ 2.5$ million USD), also by the Chinese Ministry of Agriculture (personal communication). This was directed by Youquan Shao in Shanxi, who also receives funds from CARS (\#5 in Table 2). He was specifically instructed to help farmers use honey bees for pear pollination instead of hand pollination, which was common in some northern provinces of China (Ya et al., 2003).

Notice that these numbers (Table 1 and Table 2) do not include competitive funding from the Ministry of Agriculture (USDA equivalent in China) nor the National Natural Science Foundation of China (NSFC, the NSF equivalent in China) for honey bee research. Unlike the US, in China the NSFC must award 4-6 grants to honey bee research each year, while in US, only the best among animal behavior or physiology (NSF) are funded by NSF, even in USDA grants, honey bee research must be competed in entomology and nematology, so there is no guarantee that honey bee specific proposals will be funded.
It is also quite clear that the funding provided by CARS enabled Chinese scientists to conduct many basic research projects, as evidenced by the acknowledgement of CARS in their papers (Figure 1). The number of publications per year increased significantly $(\mathrm{P}=0.03$, one tailed t-test) after CARS funded the three scientists (we assumed a two year delay in publications so we compared before and after 2010). The majority of scientists were to conduct applied research and they published mostly in Chinese trade magazines.

China has a total of 50 such groups within the apicultural system, most of them with larger group sizes than the honey bee group (CARS45). They are planning a third phase of this project (starting in 2016), and per scientist allocation is expected to increase from 700,000 yuan to 1 million ( $=\$ 164,000$ per year per person).

\section{Funding in the US}

In the US, after the initial announcement of CCD in 2006, the USDA gave the four honey bee labs (now only three are left) an "Area Wide" program for honey bee research, totaling $\$ 4$ million. Then there was a CAP (Coordinated Agricultural Project) grant specific to honey bees in 2008; entitled the "Sustainable Solutions to Problems Affecting Health of Managed Bees," this project was managed by Dr. Keith Deplane, University of Georgia and shared by about a dozen honey bee scientists (of which Zachary Y. Huang is a consortium member). Another NIFA-CAP project was funded in 2011, for a total of $\$ 5.0$ million (http://beeinformed.org), directed by Dennis vanEngelsdorp (University of Maryland). Notice that with the exception of the Area Wide Program, the two CAP grants were also competitive funding and they were funded because they won the competitive over many other, non-honey bee proposals. The original request for proposals for these two grants were not specifically limited for pollinator research. However if we exclude these two grants, then we would not have an even lower figure compared to China. Even with these two grants included, we show that the total investment into honey bee research is about 1:2.5, US:China (Table 3). We did not include other grants won competitively from NIFA, NSF or NIH, because they were not specifically designed for honey bee or pollinator research.

\section{Competitive or not?}

We are not proposing that the funding mechanism is superior in China because competition presumably improves proposal quality. Perhaps a middle road is the best: set aside research money for honey bees specifically, or pollinators in general, both in the USDA and NSF, such that a limited "quota" of proposals are funded each year for honey-bee-specific research. This will ensure both quality (through competition) of studies as well as proper resource partition for honey bee research. Given that honey bees are so important to food production, we argue that honey bees are vitally important for our food security. Undoubtedly, two recently released White House Documents (Pollinator Health Task Force, 2015a; Pollinator Health Task Force, 2015b) might create just such a specific funding mechanism 
Table 1. Names and locations of honey bee scientists funded by the Earmarked Fund for Chinese. Modern Agro-industry Technology Research System (CARS45). Each of these scientist receives 700,000 RMB ( 120,000 USD), but the chief scientist, Jie Wu receives 1,000,000 RMB ( 160,000 USD) per year from 2008 to 2015. Total funding per person during the entire period = 5.6 million RMB ( 0.9 million USD). Total funding for all scientists $\sim 19$ million USD. Funding amounts were obtained from Wu (2009). Names were obtained from http://finance.people.com.cn/GB/8215/47807/59262/14712388.html.

\begin{tabular}{|c|c|c|c|c|}
\hline Name (first LAST) & Institute & Upper Administration & City, Province & Responsibility \\
\hline 1. Jie WU & $\begin{array}{l}\text { Institute of Apicultural } \\
\text { Research }\end{array}$ & $\begin{array}{l}\text { Chinese Academy of } \\
\text { Agricultural Sciences }\end{array}$ & Beijing & $\begin{array}{l}\text { Chief Scientist, in charge of } \\
\text { the entire national program }\end{array}$ \\
\hline 2. Wei SHI & $\begin{array}{l}\text { Institute of Apicultural } \\
\text { Research }\end{array}$ & $\begin{array}{l}\text { Chinese Academy of } \\
\text { Agricultural Sciences }\end{array}$ & Beijing & $\begin{array}{l}\text { Director of the "Breeding and } \\
\text { Pollination Lab" }\end{array}$ \\
\hline 3. Songkun SU & $\begin{array}{l}\text { College of Honey Bee } \\
\text { Sciences }\end{array}$ & $\begin{array}{l}\text { Fujian Agriculture and } \\
\text { Forestry University }\end{array}$ & Fuzhou, Fujian & Breeding techniques in 2 \\
\hline 4. Yunbo XUE & $\begin{array}{l}\text { Key Laboratory for Honey } \\
\text { Bee Genetics and Queen } \\
\text { Breeding }\end{array}$ & $\begin{array}{l}\text { Jilin Provincial Institute of } \\
\text { Apicultural Science }\end{array}$ & Jilin, Jilin Province & Germplasm preservation in 2. \\
\hline 5. Youquan SHAO & $\begin{array}{l}\text { Bee Laboratory, Horticulture } \\
\text { Research Institute }\end{array}$ & $\begin{array}{l}\text { Academy of Agricultural } \\
\text { Sciences of Shanxi Province }\end{array}$ & Taiyuan, Shanxi & $\begin{array}{l}\text { Management of pollinating } \\
\text { colonies in } 2 \text {. }\end{array}$ \\
\hline 6. Ting $\mathrm{ZHOU}$ & $\begin{array}{l}\text { Institute of Apicultural } \\
\text { Research }\end{array}$ & $\begin{array}{l}\text { Chinese Academy of } \\
\text { Agricultural Sciences }\end{array}$ & Beijing & $\begin{array}{l}\text { Director of Pest Control and } \\
\text { Product-Quality Monitoring } \\
\text { Lab }\end{array}$ \\
\hline 7. Qin LIANG & $\begin{array}{l}\text { College of Honey Bee } \\
\text { Sciences }\end{array}$ & $\begin{array}{l}\text { Fujian Agriculture and } \\
\text { Forestry University }\end{array}$ & Fuzhou, Fujian & Pest and disease control in 6. \\
\hline 8. Liming WU & $\begin{array}{l}\text { Institute of Apicultural } \\
\text { Research }\end{array}$ & $\begin{array}{l}\text { Chinese Academy of } \\
\text { Agricultural Sciences }\end{array}$ & Beijing & $\begin{array}{l}\text { Pesticide residue and its } \\
\text { reduction in } 6 \text {. }\end{array}$ \\
\hline 9. Linsheng YU & $\begin{array}{l}\text { College of Animal Science } \\
\& \text { technology }\end{array}$ & Anhui Agricultural University & Hefei, Anhui & Risk assessment in 6. \\
\hline 10. Jing ZHAO & $\begin{array}{l}\text { Institute of Apicultural } \\
\text { Research }\end{array}$ & $\begin{array}{l}\text { Chinese Academy of } \\
\text { Agricultural Sciences }\end{array}$ & Beijing & $\begin{array}{l}\text { Bee product quality control } \\
\text { in } 6 \text {. }\end{array}$ \\
\hline 11. Bingfeng $\mathrm{ZHOU}$ & $\begin{array}{l}\text { Honey Bee Ecology } \\
\text { Laboratory }\end{array}$ & $\begin{array}{l}\text { Fujian Agriculture and } \\
\text { Forestry University }\end{array}$ & Fuzhou, Fujian & $\begin{array}{l}\text { Director of Beekeeping } \\
\text { Technology and Tools Lab }\end{array}$ \\
\hline 12. Zhijiang ZENG & $\begin{array}{l}\text { Institute of Honey Bee } \\
\text { Research }\end{array}$ & $\begin{array}{l}\text { Jiangxi Agricultural } \\
\text { University }\end{array}$ & Nanchang, Jiangxi & $\begin{array}{l}\text { Beekeeping for } A \text {. mellifera } \\
\text { in } 11 .\end{array}$ \\
\hline 13. Jianke LI & $\begin{array}{l}\text { Institute of Apicultural } \\
\text { Research }\end{array}$ & $\begin{array}{l}\text { Chinese Academy of } \\
\text { Agricultural Sciences }\end{array}$ & Beijing & $\begin{array}{l}\text { Migratory beekeeping and } \\
\text { tools in } 11 .\end{array}$ \\
\hline 14. Shaoyu HE & $\begin{array}{l}\text { Institute of Eastern Honey } \\
\text { Bee Research }\end{array}$ & $\begin{array}{l}\text { Yunnan Agricultural } \\
\text { University }\end{array}$ & Kunming, Yunnan & $\begin{array}{l}\text { Hive bodies and honey } \\
\text { combs in } 11 .\end{array}$ \\
\hline 15. Baohua XU & $\begin{array}{l}\text { College of Animal Sciences } \\
\text { and Veterinary Medicine }\end{array}$ & $\begin{array}{l}\text { Shandong Agricultural } \\
\text { University }\end{array}$ & Taian, Shandong & Nutrition and feed in 11. \\
\hline 16. Fuliang $\mathrm{HU}$ & College of Animal Sciences & Zhejiang University & Hangzhou, Zhejiang & $\begin{array}{l}\text { Director of Product Processing } \\
\text { and Development Lab. }\end{array}$ \\
\hline 17. Wenjun PENG & $\begin{array}{l}\text { Institute of Apicultural } \\
\text { Research }\end{array}$ & $\begin{array}{l}\text { Chinese Academy of } \\
\text { Agricultural Sciences }\end{array}$ & Beijing & Deep processing in 16. \\
\hline 18. Jie DONG & $\begin{array}{l}\text { Institute of Apicultural } \\
\text { Research }\end{array}$ & $\begin{array}{l}\text { Chinese Academy of } \\
\text { Agricultural Sciences }\end{array}$ & Beijing & $\begin{array}{l}\text { Utilization of bioactive } \\
\text { components in } 16 .\end{array}$ \\
\hline 19. Xiaoqing MIAO & $\begin{array}{l}\text { College of Honey Bee } \\
\text { Sciences }\end{array}$ & $\begin{array}{l}\text { Fujian Agriculture and } \\
\text { Forestry University }\end{array}$ & Fuzhou, Fujian & $\begin{array}{l}\text { Product development for } \\
\text { human health. }\end{array}$ \\
\hline 20. Zhijun ZHAO & $\begin{array}{l}\text { Institute of Agricultural } \\
\text { economics and development }\end{array}$ & $\begin{array}{l}\text { Chinese Academy of } \\
\text { Agricultural Sciences }\end{array}$ & Beijing & $\begin{array}{l}\text { Economics of bees and } \\
\text { beekeeping. }\end{array}$ \\
\hline
\end{tabular}


Table 2. Names and locations of honey bee experimental stations funded by the Earmarked Fund for Chinese. Modern Agro-industry Technology Research System (CARS45). Each of these scientists receives 500,000 RMB ( 83,000 USD per year 2011-2015. Eleven of them received 300,000 per year during 2008 to 2010. Total funding for al experimental stations $~ 10.2$ million USD. Funding amounts were obtained from Wu (2009). Names were obtained from http://finance.people.com.cn/GB/8215/47807/59262/14712388.html.

\begin{tabular}{|c|c|c|c|}
\hline Name (first, LAST) & Station Name & Upper Administration & City, Province \\
\hline 21. Jinzu LIU & $\begin{array}{l}\text { Beijing Experimental } \\
\text { Station }\end{array}$ & Beijing Apiculture Company & Beijing \\
\hline 22. Yingsheng ZHANG & $\begin{array}{l}\text { Jinzhong Experimental } \\
\text { Station }\end{array}$ & Bee Breading Apiary & Jinzhong, Shanxi \\
\hline 23. Chunying YUAN & $\begin{array}{l}\text { Xingcheng Experiment } \\
\text { Station }\end{array}$ & $\begin{array}{l}\text { Safety Supervision Bureau of Animal } \\
\text { Production }\end{array}$ & Shenyang, Liaoning \\
\hline 24. Qingsheng NIU & Jiling Experiment Station & $\begin{array}{l}\text { Jilin Provincial Institute of Apicultural } \\
\text { Science }\end{array}$ & Jilin, Jilin province \\
\hline 25. Fuchao GAO & $\begin{array}{l}\text { Mudang River } \\
\text { Experimental Station }\end{array}$ & $\begin{array}{l}\text { Heilongjiang Academy of Agricultural } \\
\text { Sciences }\end{array}$ & Ha'rbin, Heilongjiang \\
\hline 26. Ting ال I & $\begin{array}{l}\text { Yangzhou Experimental } \\
\text { Station }\end{array}$ & Yangzhou University & Yangzhou, Jiangsu \\
\hline 27. Qiyun HUA & $\begin{array}{l}\text { Jinhua Experimental } \\
\text { Station }\end{array}$ & $\begin{array}{l}\text { Academy of Agricultural Sciences of } \\
\text { Jinhua }\end{array}$ & Jinhua, Zhejiang \\
\hline 28. Xiangjin MENG & $\begin{array}{l}\text { Hefei Experimental } \\
\text { Station }\end{array}$ & $\begin{array}{l}\text { Master Station of Animal Husbandry } \\
\text { Technology Promotion }\end{array}$ & Hefei, Anhui \\
\hline 29. ikun ZHANG & $\begin{array}{l}\text { Taian Experimental } \\
\text { Station }\end{array}$ & $\begin{array}{l}\text { Bee Breeding Center of Shandong } \\
\text { Province }\end{array}$ & Taian, Shandong \\
\hline 30. Zhongyin ZHANG & $\begin{array}{l}\text { Xinxiang Experimental } \\
\text { Station }\end{array}$ & $\begin{array}{l}\text { Henan Institute of Science and } \\
\text { Technology }\end{array}$ & Xinxiang, Henan \\
\hline 31. Yanting LI & $\begin{array}{l}\text { Wuhan Experimental } \\
\text { Station }\end{array}$ & Baochun Royal Jelly Company & Wuhan, Hubei \\
\hline 32. Yuexiong LUO & $\begin{array}{l}\text { Guangzhou Experimental } \\
\text { Station }\end{array}$ & Guangdong Institute of Entomology & Guangzhou, Guangdong \\
\hline 33. Zheng XU & $\begin{array}{l}\text { Nanning Experimental } \\
\text { Station }\end{array}$ & $\begin{array}{l}\text { Guangxi Zhuang Autonomous } \\
\text { Region Beekeeping Advising Center }\end{array}$ & Nanning, Guangxi \\
\hline 34. Jinglin GAO & $\begin{array}{l}\text { Danzhou Experimental } \\
\text { Station }\end{array}$ & $\begin{array}{l}\text { Chinese Academy of Tropical } \\
\text { Agriculture Environment and Plant } \\
\text { Protection Institute }\end{array}$ & Danzhou, Hainan \\
\hline 35. Rongguo DAI & $\begin{array}{l}\text { Chongqing Experimental } \\
\text { Station }\end{array}$ & $\begin{array}{l}\text { Chongqing Academy of Animal } \\
\text { Husbandry }\end{array}$ & Chongqing, Sichuan \\
\hline 36. Shunhai WANG & $\begin{array}{l}\text { Chengdu Experimental } \\
\text { Station }\end{array}$ & $\begin{array}{l}\text { Sichuan Apiculture Technology } \\
\text { Exploring Institute }\end{array}$ & Chengdu, Sichuan \\
\hline 37. Xuewen ZHANG & $\begin{array}{l}\text { Honghe Experimental } \\
\text { Station }\end{array}$ & Yunnan Agricultural Academy & Kunming, Yunnan \\
\hline 38. Qinhong YANG & $\begin{array}{l}\text { Yan'an Experimental } \\
\text { Station }\end{array}$ & $\begin{array}{l}\text { Beekeeping Experimental Station of } \\
\text { Yan'an }\end{array}$ & Yan'an, Shanxi \\
\hline 39. Wenzhong QI & $\begin{array}{l}\text { Tianshui Experimental } \\
\text { Station }\end{array}$ & Institute of Beekeeping & Tianshui, Gansu \\
\hline 40. Biao WANG & $\begin{array}{l}\text { Guyuan Experimental } \\
\text { Station }\end{array}$ & $\begin{array}{l}\text { Beekeeping Experimental Station of } \\
\text { Guyuan }\end{array}$ & $\begin{array}{l}\text { Guyuan, Ningxia } \\
\text { HuiAutonomous Region }\end{array}$ \\
\hline 41. Shidong LIU & $\begin{array}{l}\text { Wulumuqi Experimental } \\
\text { Station }\end{array}$ & $\begin{array}{l}\text { Bee Breeding Farm of Xinjiang } \\
\text { Uygur Autonomous Region }\end{array}$ & $\begin{array}{l}\text { Wulumuqi, Xinjiang Uygur } \\
\text { Autonomous Region }\end{array}$ \\
\hline
\end{tabular}




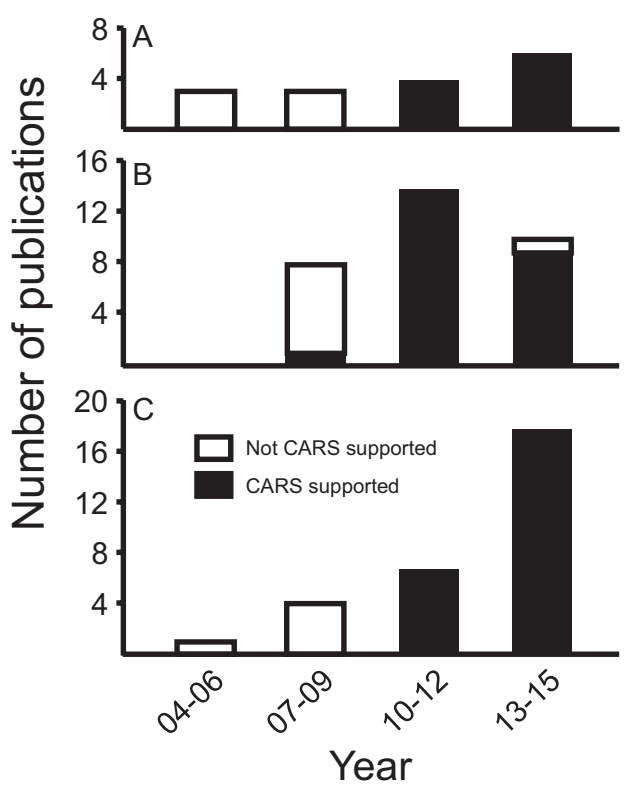

Figure 1. Number of articles published in refereed journals by three scientists in China (Songkun Su, Jianke Li and Zhijiang Zeng, respectively for A, B and C, respectively). Nearly all papers published after 2010 acknowledged CARS funding (dark column).

so that food production by honey bees can be ensured. We therefore welcome this much needed change in the right direction.

Author contributions

ZYH conceived the concept of this paper, SL and XX did data gathering for Table 1 and Table 2. All three wrote the paper.

Competing interests

We declare no competing interests.
Table 3. Comparative investment (millions in USD) into honey bee research in China and USA between 2008 and 2015. Competitive grants are excluded in both countries except the NIFA grants in USA. We used a ratio of $1 \mathrm{USD}=6.1$ Chinese Yuan for currency conversion. Data for USA is from Purcell-Miramontes (2013), data for China was obtained from Wu (2009).

\begin{tabular}{|l|r|}
\hline China & \\
\hline 1. CARS scientists (Table 1) & 19.0 \\
\hline 2. CARS stations (Table 2) & 10.2 \\
\hline 3. Pear Pollination Project & 2.5 \\
\hline Total & 31.7 \\
\hline USA & \\
\hline Area-wide program to Honey Bee Labs & 5.0 \\
\hline $\begin{array}{l}\text { NIFA-CAP (UGA, 20098511805718), } \\
\text { competitive (2008) }\end{array}$ & 4.1 \\
\hline $\begin{array}{l}\text { NIFA-CAP (Beelnformed, 2011-6700730355), } \\
\text { competitive (2011) }\end{array}$ & 5.0 \\
\hline \begin{tabular}{l} 
Total \\
\hline
\end{tabular} & 14.1 \\
\hline
\end{tabular}

Grant information

XX was supported by National Natural Science Foundation of China (\#31302040) and Natural Science Foundation of Fujian Province (\#2010J05081).

I confirm that the funders had no role in study design, data collection and analysis, decision to publish, or preparation of the manuscript.

Acknowledgement

We thank Melissa Huang for improving this manuscript.
Cox-Foster DL, Conlan S, Holmes EC, et al:: A metagenomic survey of microbes in honey bee colony collapse disorder. Science. 2007; 318(5848): 283-287. PubMed Abstract | Publisher Full Text

Gallai N, Salles JM, Settele J, et al.: Economic valuation of the vulnerability of world agriculture confronted with pollinator decline. Ecol Econ. 2009; 68(3): 810-821. Publisher Full Text

Morse RA, Calderone NW: The Value of Honey Bees as Pollinators of U.S. Crops in 2000. Bee Culture. 2000; 128: 1-15.

Reference Source

Pollinator Health Task Force. Pollinator research action plan. Washington: The White House, 2015a.

Reference Source

Pollinator Health Task Force. National strategy to promote the health of honey bees and other pollinators. Washington: The White House, 2015b.

Reference Source
Purcell-Miramontes MF: Colony collapse disorder (CCD), federal funding and the challenges of bee decline research: a bureaucrat's perspective. American Bee Journal. 2013; 153: 431-433.

Reference Source

Vander Zee R, Pisa L, Andonov S, et al: Managed honey bee colony losses in Canada, China, Europe, Israel and Turkey, for the winters of 2008-9 and 2009-10. J Apic Res. 2012; 51(1): 100-114.

Publisher Full Text

Wu J: Brief description of the apicultural group in the Chinese Agricultural Research System. Apiculture of China, 2009; 60: 18-20.

Ya T, Xie JS, Chen KM: Hand Pollination of Pears and its Implications for Biodiversity Conservation and Environmental Protection - A case study from Hanyuan County, Sichuan Province, China. College of the Environment, Sichuan University, Chengdu, CN. 2003.

Reference Source 
The benefits of publishing with F1000Research:

- Your article is published within days, with no editorial bias

- You can publish traditional articles, null/negative results, case reports, data notes and more

- The peer review process is transparent and collaborative

- Your article is indexed in PubMed after passing peer review

- Dedicated customer support at every stage

For pre-submission enquiries, contact research@f1000.com 